\title{
Fabrication and Characterization of Antibacterial Titanium Dioxide Nanorods Incorporating Gellan Gum Films
}

\author{
Mohd Hasmizam Razali* (D), Nur Arifah Ismail and Khairul Anuar Mat Amin (iD \\ School of Fundamental Sciences, Universiti Malaysia Terengganu, 21030 Kuala Terengganu, \\ Terengganu Darul Iman, Malaysia.
}

\begin{abstract}
The aim of this work was to develop bionanocomposite films based biopolymer GG and $\mathrm{TiO}_{2}-\mathrm{NRs}$ for active food packaging. The $\mathrm{TiO}_{2}$-NRs were incorporated as antimicrobials agent into GG via solvent casting method. The films appearance was have $94 \%$ of transparency. SEM micrographs indicate that the $\mathrm{TiO}_{2}$-NRs were successfully incorporated and attached to the surface of developed GG films. FTIR results revealed the interaction between $\mathrm{TiO}_{2}$ NRs and hydroxyl group of GG polymer. XRD results showed the crystalline peaks of $\mathrm{TiO}_{2}-\mathrm{NRs}$ and amorphous peaks of GG+TiO -NRs films. The thermal stability of $\mathrm{GG}$ films were increasing by incorporation of $\mathrm{TiO}_{2}-\mathrm{NRs}$ materials. The GG+TiO ${ }_{2}$-NRs films showed good antibacterial activity against Gram-positive (Staphylococcus aureus (S. aureus) and Streptococcus (strep.)) and Gram-negative (Escherichia coli (E. coli) and Pseudomonas aeruginosa (P. aeruginosa)) and potentially used as antibacterial packaging films.
\end{abstract}

Keywords: gellan gum, $\mathrm{TiO}_{2}$-NRs, films, antibacterial.

*Correspondence: mdhasmizam@umt.edu.my

(Received: 21 July 2019; accepted: 10 September 2019)

Citation: Mohd Hasmizam Razali, Nur Arifah Ismail and Khairul Anuar Mat Amin, Fabrication and Characterization of Antibacteria Titanium Dioxide Nanorods Incorporating Gellan Gum Films, J Pure Appl Microbiol., 2019; 13(4):1909-1916. https://doi. org/10.22207/JPAM.13.4.03

(C) The Author(s) 2019. Open Access. This article is distributed under the terms of the Creative Commons Attribution 4.0 International License which permits unrestricted use, sharing, distribution, and reproduction in any medium, provided you give appropriate credit to the original author(s) and the source, provide a link to the Creative Commons license, and indicate if changes were made. 


\section{INTRODUCTION}

The most favourable biopolymers that are currently used commercially and have been extensive study is gellan gum (GG). GG is an anionic straight chain biopolymer containing $\beta$-D-glucose, $\alpha$-L-rhamnose and $\beta$-D-glucuronate residues ${ }^{1}$ and usefulness industrially due to its unique structure and physical properties. Previously, GG has been approached in wound healing study ${ }^{2,3}$ as well as candidate material for tissue engineering application ${ }^{4}$ and hold a vital role in pharmaceutical. Since 1992, this materials were approved to be utilized in food industry by the US FDA (United States Food and Drug Administration) and the EU (European Union) regulation classified as $E$ $415^{5}$. GG polymers have been used in varied application included as agar replacement due to its excellent gelling properties as well as highly purified polysaccharide. It has high potential to be apply in industrial as a high-viscosity biogum, a suspending agent and acts as a gelling agent ${ }^{6}$. Not limited to that, GG has been utilized for personal care included in cosmetics and toiletries products ${ }^{7}$. It has thermal stability, clarity and compatibility with nutrient additives ${ }^{8}$. Thus, it's stable at varied temperatures and can offer an excellent stability for varied applications.

$\mathrm{TiO}_{2}$ nanostructured can be found in four dimension which is $0-D, 1-D, 2-D$, and 3-D. It have been create a huge impact on the nanodevices, nanocomposite materials, nanoelectronics, and etc. ${ }^{9}$ due to their unique and large surface areas properties. Apart from that, due to the high surface area as well as provided enough absorption sites for all involved molecules in a small space, the $\mathrm{TiO}_{2}$ nanostructured materials become subject of interest in the research field ${ }^{10}$. Nowadays, the development based on the nanostructured are getting highest ranking over the world either in nanotechnology or nanobiotechnology disciplinary due to their peculiar and fascinating properties. The utilization of $\mathrm{TiO}_{2}$ nanostructured have been explored widely as a polymers, metals, and ceramics. Their applications not only limit to against human pathogen likes bacteria but also to fight cancer and its was become focal subject in research and applications due to their potent bactericidal activity to against a resistant strains of pathogens. $\mathrm{TiO}_{2}$ is one of the inorganic materials that have getting special interest to be applied in inorganic and organic nanocomposites ${ }^{11}$. Among the versatile of $\mathrm{TiO}_{2}$ nanostructured family, $\mathrm{TiO}_{2}$-NRs have become subject of interest and it's typically in 1-D formation and consists of solid elongated structure. Previously, $\mathrm{TiO}_{2}$-NRs have been used in development of glucose biosensor ${ }^{12}$, facilitate the DET (direct electron transfer) of GOx (glucose oxidase) ${ }^{13,14}$, in immunotherapy for cancer therapy application $^{15}$, and also as a photoelectrochemical immunosensor ${ }^{16}$. Not limited to that, due to its high extraction proficiency, enhanced for mechanical strength, and outstanding in stability, $\mathrm{TiO}_{2}$-NRs display an excellent extraction performance as solid-phase microextraction (SPME) coatings ${ }^{17}$. Above all, $\mathrm{TiO}_{2}$ is a popular substance in varied application regarding to their properties which is chemically and thermally stable, nature friendly, be biocompatible, cheap, and anti-corrosion.

Therefore, in this study, GG and $\mathrm{TiO}_{2}$ nanostructured was became an interesting candidate material to be explored as an active food packaging regarding to the environmental concern. The developments of biomaterials as an active food packaging were important in reducing the environmental pollution that causes from accumulation of synthetic packaging. Thus, $\mathrm{GG}+\mathrm{TiO}_{2}-\mathrm{NRs}$ films were prepared and characterized using UV, SEM, FTIR, XRD, and TGA and the performance of antibacterial properties also were evaluated.

\section{EXPERIMENTAL}

Prior to the fabrication of film, $\mathrm{TiO}_{2}$ nanorods was prepared using hydrothermal method $^{18}$. In order to prepare $G G$ incorporating $1 \mathrm{wt} \% \mathrm{TiO}_{2}-\mathrm{NRs}\left(\mathrm{GG}+\mathrm{TiO}_{2}\right.$-NRs) film, $0.01 \mathrm{gram}$ of synthesized $\mathrm{TiO}_{2}$-NRs was added into the $100 \mathrm{ml}$ of GG solution. The GG solution was prepare earlier by dissolving 1 gram of GG into $100 \mathrm{ml}$ distilled water. The solution was stirred continuously for 2 hours at $70^{\circ} \mathrm{C}$. Then the homogeneous solution was poured into the casting plate and was dried at $50^{\circ} \mathrm{C}$ for $24 \mathrm{~h}$. The films were preconditions for $\geq 48$ $h$ in the humidity chamber at controlled conditions (relative humidity $50 \%$ at room temperature). The pristine GG films were fabricated using similar technique excluding the addition of $\mathrm{TiO}_{2}$-NRs.

Ultraviolet-visible (U'V-Vis) transmission was conducted using Varian, Cary 50 spectrophotometer at $200-800 \mathrm{~nm}$ of 
wavelength. Tecnai Biotwin FEI transmission electron microscopy (TEM) was used to observe the $\mathrm{TiO}_{2}$ nanorods appearance. The morphological images of samples were observed by JOEL JSM 6360 LA electron microscopy. Fourier Transform Infrared Spectroscopy (FTIR) spectra were verified using a Perkin Elmer Spectrum 100 FTIR spectrophotometer with a PIKE Miracle ATR accessory at 4000 to $600 \mathrm{~cm}^{-1}$. XRD analysis was recorded using Rigaku Miniflex (II) X-ray diffractometer from $10^{\circ}$ to $80^{\circ}$ of 2 thetha. Thermogravimetric analysis was done using Pyris 6 , Perkin-Elmer-TGA6 with heating rate at $10^{\circ} \mathrm{C} /$ min from room temperature to $1000{ }^{\circ} \mathrm{C}$ in an atmosphere of $\mathrm{N}_{2}$ flow at $50 \mathrm{ml} / \mathrm{min}$.

The antibacterial activity of nanostructured $\mathrm{TiO}_{2}$ materials were established by inhibition ring method under UV light irradiation conditions using four types of bacteria which is S. aureus, Strep., E. coli, and P. aeruginosa ${ }^{19}$. At 0.5 McFarland standards, inoculants of each bacteria were evenly spread in sterile petri plates contained the $\mathrm{MH}$ agar. Antibacterial properties were evaluated by measuring the transparent antibacterial circle diameter of the materials surrounding bacterial growth after 24 hours.

\section{RESULTS AND DISCUSSION}

Fig. 1a shows the photo images of gellan gum (GG) and gellan gum with the addition of titanium dioxide nanorods $\left(\mathrm{GG}+\mathrm{TiO}_{2}-\mathrm{NRs}\right)$. The diameter and thickness of both films were almost similar which are $\sim 9 \mathrm{~cm}$ and $\sim 60 \mu \mathrm{m}$, respectively. The optical transparency of films was evaluated

(a)
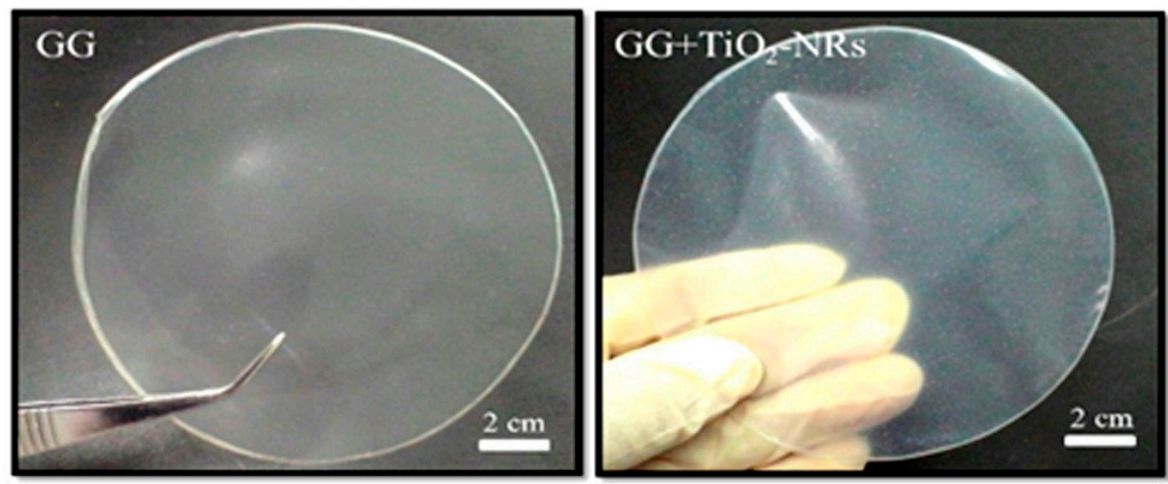

(b)

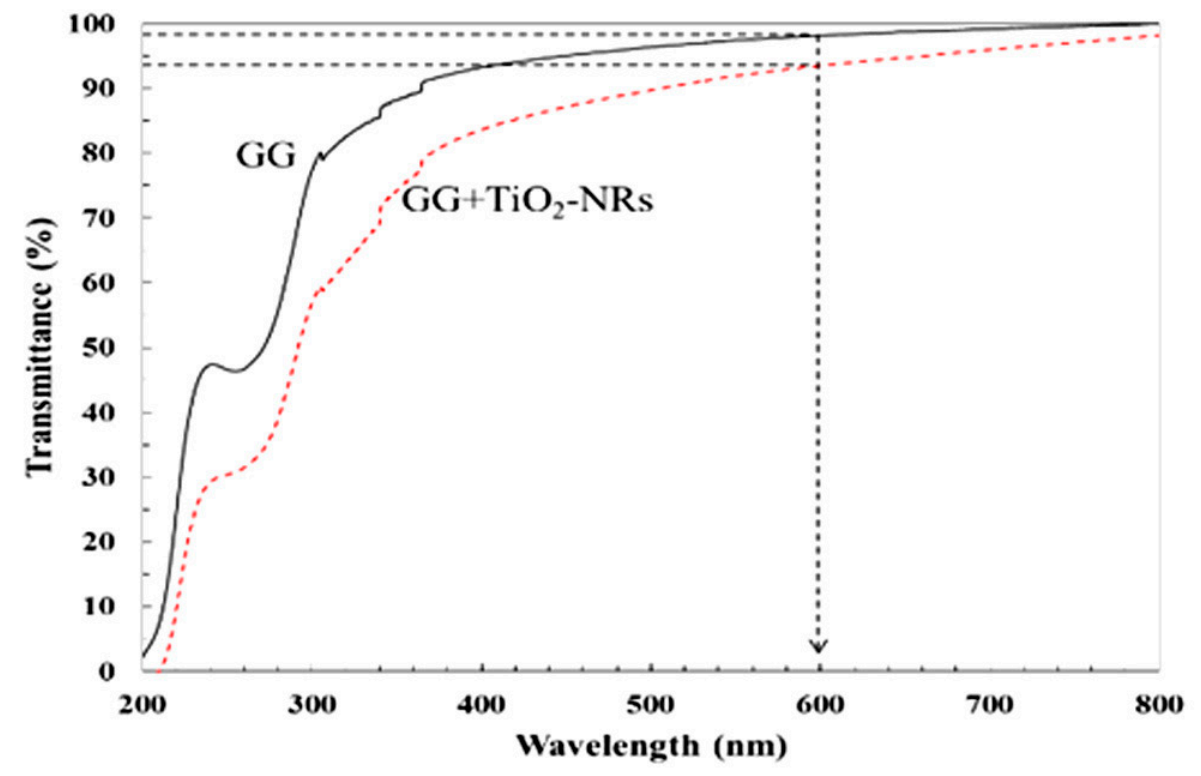

Fig. 1. (a) Physical appearance of $\mathrm{GG}$ and $\mathrm{GG}+\mathrm{TiO}_{2}-\mathrm{NRs}$ (b) UV-Vis transmittance of $\mathrm{GG}$ and $\mathrm{GG}+\mathrm{TiO}_{2}-\mathrm{NRs}$ films 
by UV-visible analysis. The $\mathrm{GG}$ and $\mathrm{GG}+\mathrm{TiO}_{2}-$ NRs films were transparent with transmittance values were $98 \%$ and $94 \%$, respectively (Fig. 1b). Fig. 2a displays the TEM images of $\mathrm{TiO}_{2}$-NRs samples. Its exhibits elongated nanostructures (rod-like particles) proposed that the nanorods were successfully obtained. The diameter and length of rod-like particles was found to be 25 $50 \mathrm{~nm}$ and $2.25-3.25 \mu \mathrm{m}$, respectively. Fig. $2 \mathrm{~b}$ shows smooth and homogeneous surface of GG films. In contrast, less homogenous surface was observed on $\mathrm{GG}+\mathrm{TiO}_{2}-\mathrm{NRs}$ films attributed to the agglomeration of $\mathrm{TiO}_{2}$-NRs into and onto $\mathrm{GG}$ film and contributed to the rough film surfaces that may beneficial for antibacterial activity.

The FTIR spectra of $\mathrm{TiO}_{2}-\mathrm{NRs}, \mathrm{GG}$, and $\mathrm{GG}+\mathrm{TiO}_{2}-\mathrm{NRs}$ films are demonstrated in Fig. 3. A broad peak below $1000 \mathrm{~cm}^{-1}$ has been detected in

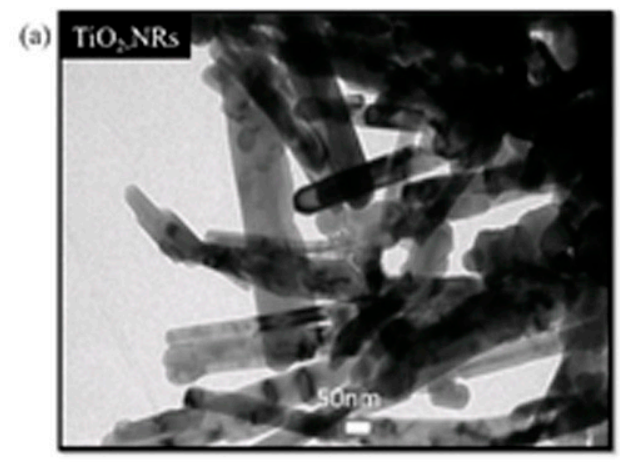

(b)
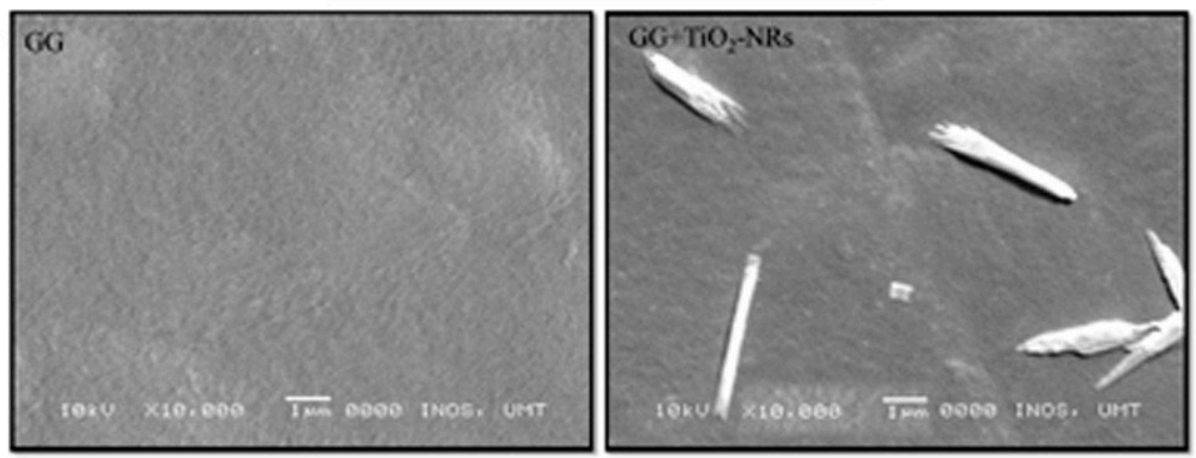

Fig. 2. (a) TEM micrographs of $\mathrm{TiO}_{2}-\mathrm{NRs}$ (b) $\mathrm{SEM}$ micrographs of $\mathrm{GG}$ and $\mathrm{GG}+\mathrm{TiO}{ }_{2}-\mathrm{NRs}$ films

the $\mathrm{TiO}_{2}-\mathrm{NRs}$ and $\mathrm{GG}+\mathrm{TiO}_{2}-\mathrm{NRs}$ spectrum, which is attributed to metal-oxygen (Ti-O) stretching mode. Apart from that, a broad peak also was display by $\mathrm{GG}$ spectra assigned to $\mathrm{OH}$ stretching vibrations modes at $3408 \mathrm{~cm}^{-1}$, carbonyl group at $1666 \mathrm{~cm}^{-1}$ and C-C aromatic stretching at $1424 \mathrm{~cm}^{-120}$. FTIR spectra of GG films also show a prominent peak at $2936 \mathrm{~cm}^{-1}$ and $1043 \mathrm{~cm}^{-1}$ due to the $\mathrm{C}-\mathrm{H}$ stretching modes and glycosidic bonds linking to galacturonic sugar unit in GG chain ${ }^{21}$. Last but not least, another peak was appeared at $692 \mathrm{~cm}^{-1}$ attributed to the $\mathrm{C}-\mathrm{H}$ bending mode. Similar peaks were observed in $\mathrm{GG}+\mathrm{TiO}_{2}-\mathrm{NRs}$ films as $\mathrm{GG}$, with slightly different in intensity and peak positions due to the interactions among $\mathrm{TiO}_{2}$ nanostructures and GG biopolymer chain.

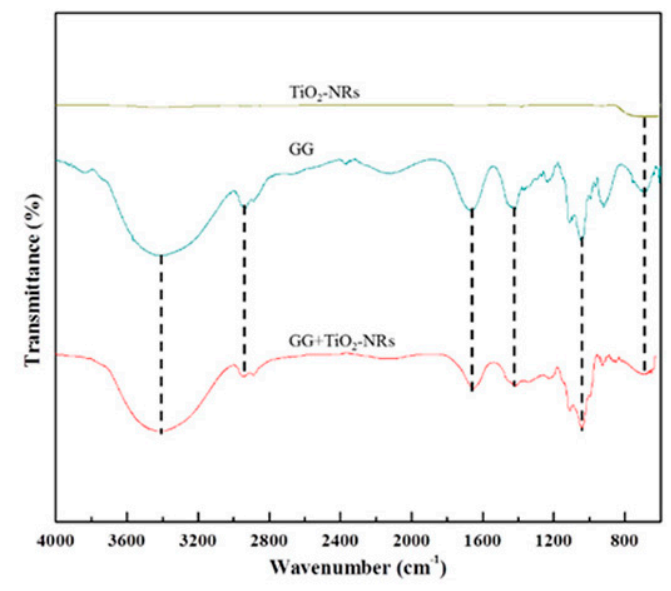

Fig. 3. FTIR spectra of $\mathrm{TiO}_{2}-\mathrm{NRs}, \mathrm{GG}$, and $\mathrm{GG}+\mathrm{TiO}_{2}-\mathrm{NRs}$ films 
Fig. 4 displays the XRD (X-ray diffraction) difractogram of of TiO2-NRs, GG, and GG+TiO ${ }_{2}-\mathrm{NRs}$ films. $\mathrm{TiO}_{2}$-NRs presented sharp peaks at $25^{\circ}, 38^{\circ}$, $48^{\circ}, 54^{\circ}, 55^{\circ}, 63^{\circ}, 69^{\circ}, 70^{\circ}$, and $75^{\circ}$ assigned to (011), (004), (020), (015), (121), (024), (116), (220) and (125) planes of anatase $\mathrm{TiO}_{2}{ }^{22}$. The sharp peaks of anatase $\mathrm{TiO}_{2}$ proposed that crystalline $\mathrm{TiO}_{2}$-NRs were produced in this study. In contrast, broad peaks which are assigned to amorphous behavior were found at $18^{\circ}$ and $21^{\circ}$ for both $\mathrm{GG}$ and $\mathrm{GG}+\mathrm{TiO}_{2}-\mathrm{NRs}$ films. These peaks were corresponded to the characteristics of $\mathrm{GG}$ chains aligned through intermolecular interactions. Additionally, for $\mathrm{GG}+\mathrm{TiO}_{2}-\mathrm{NRs}$ films, one peak with low intensity at $25^{\circ}$ was appeared suggesting that $\mathrm{TiO}_{2}$-NRs were successfully incorporated into GG films. This crystalline peak appeared at low intensity due to the small amount of $\mathrm{TiO}_{2}$ nanostructures incorporated into GG films and it more apparently appear at high concentration of $\mathrm{TiO}_{2}$ nanostructures.

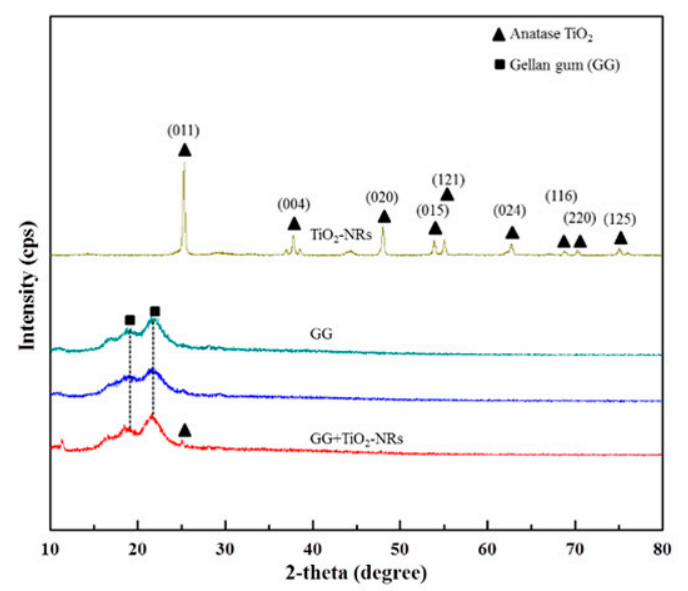

Fig. 4. XRD diffractogram of $\mathrm{TiO}_{2}-\mathrm{NRs}, \mathrm{GG}$, and $\mathrm{GG}+\mathrm{TiO}_{2}-$ NRs films

Fig. 5 shows the thermogram of $\mathrm{GG}$ and $\mathrm{GG}+\mathrm{TiO}_{2}-\mathrm{NRs}$ films. At the 1st stage, the thermal stability shows $18 \%$ of weight loss due to the moisture removal from $\mathrm{GG}$ and $\mathrm{GG}+\mathrm{TiO}_{2}-$ NRs surface. A weight loss at $58 \%(\mathrm{GG})$ and $54 \%$ (GG+TiO $-\mathrm{NRs}$ ) in 2nd stage assigned to the depolymerisation and degradation of GG biopolymer chain. A broad decomposition range of $G G$ was observed suggesting to the homogeny distribution of $\mathrm{TiO}_{2}$-NRs in the nano-composites films. It might be due to the hydrogen bonds formation as well as coordinate interaction between $\mathrm{TiO}_{2}$ and GG. Addition of $\mathrm{TiO}_{2}$-NRs into $G G$ increased the temperature to end up the degradation step regarding to the final temperature were verified at $390^{\circ} \mathrm{C}$ for $\mathrm{GG}+\mathrm{TiO}_{2}-$ NRs films showed it contains higher heat resistant. Addition of $\mathrm{TiO}_{2}$-NRs exhibits better outcome in thermal stability regarding to the certain degree of interaction between $\mathrm{GG}$ and $\mathrm{TiO}_{2}-\mathrm{NRs}$ as revealed

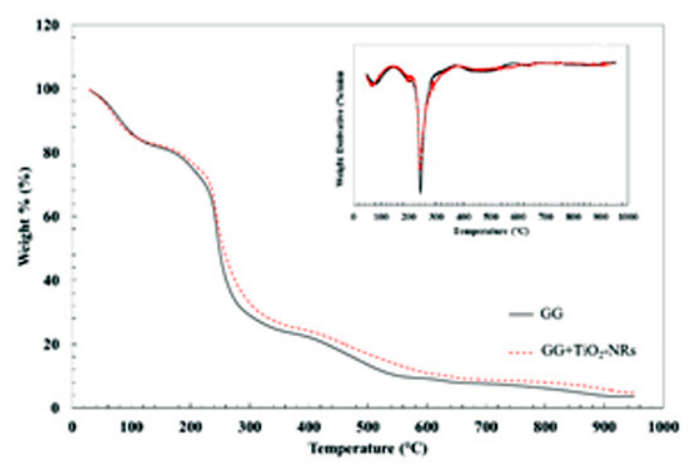

Fig. 5. TGA thermogram of $\mathrm{GG}$ and $\mathrm{GG}+\mathrm{TiO}_{2}-\mathrm{NRs}$ films

\section{by FTIR spectroscopy.}

Fig. 6 shows no antibacterial activities were found after $24 \mathrm{~h}$ incubation of pure GG film for all the bacteria. However, the inhibition zone was recorded using $\mathrm{GG}+\mathrm{TiO}_{2}$-NRs films at $10 \pm 0.35$ $\mathrm{mm}, 12 \pm 0.06 \mathrm{~mm}, 11 \pm 0.06 \mathrm{~mm}$, and $10 \pm 0.38 \mathrm{~mm}$ against S. aureus, Strep., E. coli, and P. aeruginosa which is comparable with penicillin control sample (Table 1). Good antibacterial activity by $\mathrm{GG}+\mathrm{TiO}_{2}-\mathrm{NRs}$ films was due to the presence of $\mathrm{TiO}_{2}$ nanostructures which is promoted the ROS (reactive oxygen species) generation, release of metal ion, malfunction of membrane system, and internalization of nanoparticles ${ }^{23}$. With the present of UV light, the $\mathrm{TiO}_{2}$-NRs that were incorporated into GG films produced ROS species (eg. $\mathrm{HOO} \bullet$, $\mathrm{HO} \bullet$, and $\bullet \mathrm{O}_{2}$-) from $\mathrm{O}_{2}$ and $\mathrm{H}_{2} \mathrm{O}$ through reduction reaction. The electron in the $\mathrm{TiO}_{2}$ conduction band will leave a positive hole in the valence band when the TiO2-NRs are irradiated by UV. Then, the photo-generated electron will react with molecular oxygen as well as with water to produce superoxide radical anions $\left(\bullet \mathrm{O}_{2}-\right)$ and hydroxyl $(\bullet \mathrm{OH})$ radicals, respectively. Therefore, these reactive radicals will executed the bacteria by decomposed the 
organic compounds in bacterial cells ${ }^{24-28}$. The result obtained suggesting that, $\mathrm{TiO}_{2}-\mathrm{NRs}$ is a promising antibacterial agent as $\mathrm{GG}+\mathrm{TiO}_{2}$-NRs films exhibited excellent antimicrobial property.
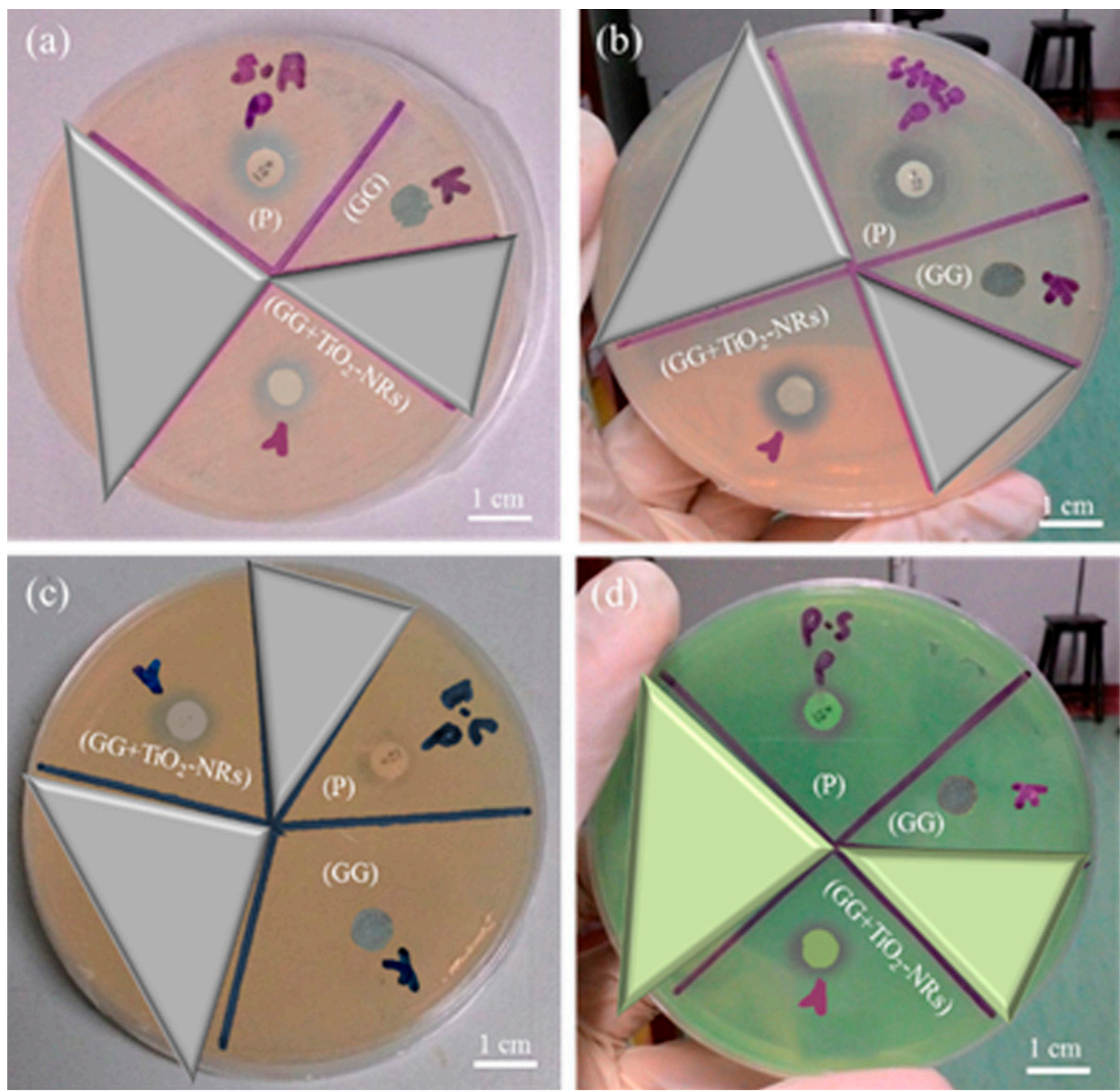

Fig. 6. Antimicrobial activity of GG and GG+TiO2-NRs films against (a) Staphylococcus aureus, (b) Streptococcus, (c) Escherichia coli, and (d) Pseudomonas aeruginosa

Table 1. Inhibition zone of films against Staphylococcus aureus, Streptococcus, Escherichia coli, and Pseudomonas aeruginosa

\begin{tabular}{lcccc}
\hline $\begin{array}{l}\text { Sample/Inhibition } \\
\text { Diameter }(\mathrm{mm})\end{array}$ & S. aureus & Strep. & E. coli & P. aeruginosa \\
\hline Penicillin & $12 \pm 0.06$ & $12 \pm 0.06$ & $10 \pm 0.12$ & $9 \pm 0.06$ \\
GG & - & - & - & - \\
GG $+\mathrm{TiO}_{2}$-NRs & $10 \pm 0.35$ & $12 \pm 0.06$ & $11 \pm 0.06$ & $10 \pm 0.38$ \\
\hline
\end{tabular}

(Data presented are mean $\pm S D, n=3$ ) 


\section{CONCLUSION}

$\mathrm{GG}+\mathrm{TiO}_{2}$-NRs film was successfully developed by solvent casting technique. The transparency of films was reduced from $98 \%$ to $94 \%$ when the $\mathrm{TiO}_{2}$-NRs were added into GG films. FTIR, XRD, and TGA results obtained exhibited the interaction of $\mathrm{TiO}_{2}$ nanorods with the $\mathrm{GG}$ polymer chain. SEM micrograph shows the presence of $\mathrm{TiO}_{2}$ nanorods on the surface of film and were enhanced the antibacterial activity.

\section{ACKNOWLEDGEMENTS}

The authors are grateful to Universiti Malaysia Terengganu (UMT) for providing the facilities to carry out this project and Ministry of Education, Malaysia for the financial support vote FRGS 59571 and MyBrain 15.

\section{CONFLICTS OF INTEREST}

The authors declare that there is no conflict of interest.

\section{FUNDING}

This study was supported by research grant FRGS 59571 and MyBrain 15 from Ministry of Education, Malaysia.

\section{AUTHOR'S CONTRIBUTION}

All authors listed have made a substantial, direct and intellectual contribution to the work, and approved it for publication.

\section{DATA AVAILABILITY}

All datasets generated or analyzed during this study are included in the manuscript and/or the Supplementary Files.

\section{ETHICS STATEMENT}

This article does not contain any studies with human participants or animals performed by any of the authors.

\section{REFERENCES}

1. Fasolin, LH, Picone, CSF, Santana, RC, Cunha, RL. Production of hybrid gels from polysorbate and gellan gum. Food research International, 54 (1) 2013: pp. 501507. https://doi.org/10.1016/j.foodres.2013.07.026

2. Ismail, NA, Mohamad, SF, Ibrahim, MA, Mat Amin, KA. Evaluation of Gellan Gum Film Containing Virgin Coconut Oil for Transparent Dressing Materials Advances in Biomaterials 2014, 2014. https://doi. org $/ 10.1155 / 2014 / 351248$

3. Ismail, NA, Mat Amin, KA, Razali, MH. Novel gellan gum incorporated $\mathrm{TiO}_{2}$ nanotubes film for skin tissue engineering. Materials Letters 228 2018: pp. 116-120. https://doi.org/10.1016/j.matlet.2018.05.140

4. Silva, NA, Cooke, MJ, Tam, RY, Sousa, N, Salgado, AJ, Reis, RL, Shoichet, MS. The effects of peptide modified gellan gum and olfactory ensheathing glia cells on neural stem/progenitor cell fate Biomaterials $\mathbf{3 3}$ (27) 2012: pp. 6345-6354. https://doi.org/10.1016/j. biomaterials.2012.05.050

5. Pszczola, DE. Gellan gum wins IFT's food technology industrial achievement award. Food Technology 47 (9) 1993: pp. 94-96.

6. Lee, MW, Chen, HJ, Tsao, SW. Preparation, characterization and biological properties of Gellan gum films with 1-ethyl-3-(3-dimethylaminopropyl) carbodiimide cross-linker Carbohydrate Polymers $\mathbf{8 2}$ (3): 2010: pp. 920-926. https://doi.org/10.1016/j. carbpol.2010.06.019

7. Prajapati, VD, Jani, GK, Zala, BS, Khutliwala, TA. An insight into the emerging exopolysaccharide gellan gum as a novel polymer Carbohydrate Polymers 93 (2): 2013: pp. 670-678. https://doi.org/10.1016/j. carbpol.2013.01.030

8. Ismail, NA, Amin, KAM, Razali, MH. Antibacterial Study of Gellan Gum (GG) Film Incorporated Norfloxacin. J Pure Appl Microbiol, 13(2): 2019: pp.1095-1102. https://doi.org/10.22207/JPAM.13.2.48

9. Kuchibhatla, SVNT, Karakoti, AS, Bera, D, Seal, S. One dimensional nanostructured materials Progress in Materials Science 52 (5) 2007: pp. 699-913. https:// doi.org/10.1016/j.pmatsci.2006.08.001

10. Shen, $\mathrm{Q}$, Jiang, L, Zhang, H, Min, Q, Hou, W, Zhu, JJ. Three-dimensional dendritic Pt nanostructures: Sonoelectrochemical synthesis and electrochemical applications Journal of Physical Chemistry C, 112(42) 2008: pp. 16385-16392. https://doi.org/10.1021/ jp8060043

11. Nguyen, VG, Thai, H, Mai, DH, Tran, HT, Tran, DL, Vu, MT. Effect of titanium dioxide on the properties of polyethylene/ $\mathrm{TiO}_{2}$ nanocomposites Composites: Part B 45 2013: pp. 1192-1198. https://doi.org/10.1016/j. compositesb.2012.09.058

12. Zhang, J, Yu, X, Guo, W, Qiu, J, Mou, X, Li, A, Liu, H. Construction of titanium dioxide nanorod/graphite microfiber hybrid electrodes for a high performance electrochemical glucose biosensor Nanoscale 8 (17): 2016: pp. 9382-9389. https://doi.org/10.1039/ C6NR01360K

13. Liu, S, Chen, A. Coadsorption of horseradish peroxidase with thionine on $\mathrm{TiO}_{2}$ nanotubes for biosensing Langmuir 21 (18) 2005: pp. 8409-8413. https://doi. org/10.1021/la050875x

14. Topoglidis, E, Campbell, CJ, Cass, AE, Durrant, JR. Factors that affect protein adsorption on nanostructured titania films. A novel spectroelectrochemical application to sensing Langmuir 17 (25) 2001: pp. 7899-7906. https://doi.org/10.1021/la010309b

15. Wang, Y, Yao, C, Ding, L, Li, C, Wang, J, Wu, M, Lei, Y. Enhancement of the Immune Function by Titanium Dioxide Nanorods and Their Application in Cancer 
Immunotherapy Journal of biomedical nanotechnology 13(4): 2017: pp. 367-380. https://doi.org/10.1166/ jbn.2017.2323

16. Qileng, A, Cai, Y, Wei, J, Lei, H, Liu, W, Zhang, $\mathrm{S}$, Liu, Y. Construction of CdS/B-TiO nanorods photoelectrochemical immunosensor for the detection of microcystin-LR using SiO2@ G-quadruplex as multi-amplifier Sensors and Actuators B: Chemical, 254, 2018: pp. 727-735. https://doi.org/10.1016/j. snb.2017.07.164

17. Tian, $\mathrm{Y}$, Feng, J, Bu, Y, Wang, $\mathrm{X}$, Luo, C, Sun, M. In-situ hydrothermal synthesis of titanium dioxide nanorods on titanium wire for solid-phase microextraction of polycyclic aromatic hydrocarbons Analytical and Bioanalytical Chemistry 409 (16) 2017: pp. 4071-4078. https://doi.org/10.1007/s00216-017-0353-3

18. Razali, MH, Ismail, NA, Amin, KAM. Study on Phase Transition of Hydrothermally Synthesized 1-D Titanate into Titania $\left(\mathrm{TiO}_{2}\right)$ as a Potential Nanobiomaterials International Journal of Applied Chemistry, 12 (4) 2016 : pp. 629-634.

19. Razali, MH, Ismail, NA, Amin, KAM. Nanostructured $\mathrm{TiO}_{2}$ Materials: Preparation, Properties and Potential Applications (3P's) Solid State Phenomena. 266, 2017: pp. 84-89. https://doi.org/10.4028/www.scientific. net/SSP.266.84

20. Diaz-Visurraga, J, Melendrez, M, Garcia, A, Paulraj, M, Cardenas, G, Semitransparent chitosan- $\mathrm{TiO}_{2}$ nanotubes composite film for food package applications Journal of Applied Polymer Science 116 (6): 2010: pp. 3503-3515. https://doi.org/10.1002/app.31881

21. Xu, X, Li, B, Kennedy, J, Xie, B, Huang, M. Characterization of konjac glucomannan-gellan gum blend films and their suitability for release of nisin incorporated therein Carbohydrate Polymers 70 (2) 2007: pp. 192197. https://doi.org/10.1016/j.carbpol.2007.03.017

22. Mishra, RK, Majeed, ABA. , Banthia, AK. Development and characterization of pectin/gelatin hydrogel membranes for wound dressing International Journal of Plastics Technology 15 (1) 2011: pp. 82-95. https:// doi.org/10.1007/s12588-011-9016-y

23. Alavarse, AC, de Oliveira Silva, FW, Colque, JT, da Silva, VM, Prieto, T, Venancio, EC, Bonvent, JJ. Tetracycline hydrochloride-loaded electrospun nanofibers mats based on PVA and chitosan for wound dressing Materials Science and Engineering: C, 77, 2017: pp. 271-281. https://doi.org/10.1016/j.msec.2017.03.199

24. Qi, K, Cheng, B, Yu, J, Ho, W. Review on the improvement of the photocatalytic and antibacterial activities of $\mathrm{ZnO}$ Journal of Alloys and Compounds 727, 2017: pp. 792-820. https://doi.org/10.1016/j. jallcom.2017.08.142

25. Fujishima, A, Rao, TN, and Tryk, DA. Titanium dioxide photocatalysis. J Photochem and Photobiol. C: Photochemistry Reviews 1(1): 2000: pp. 1-21. https:// doi.org/10.1016/S1389-5567(00)00002-2

26. Nakayama, N, Hayashi, T. Preparation and characterization of poly (L-lactic acid)/TiO, nanoparticle nanocomposite films with high transparency and efficient photodegradability Polymer degradation and stability 92 (7): 2007: pp. 1255-1264. https://doi. org/10.1016/j.polymdegradstab.2007.03.026

27. Desai, VS, Meenal, K. Antimicrobial activity of titanium dioxide nanoparticles synthesized by sol-gel technique Research Journal of Microbiology 4 (3) 2009: pp. 97103. https://doi.org/10.3923/jm.2009.97.103

28. Ismail, NA, Amin, KAM, Majid, FAA and Razali, $\mathrm{MH}$. Gellan gum incorporating titanium dioxide nanoparticles biofilm as wound dressing: Physicochemical, mechanical, antibacterial properties and wound healing studies. Materials Science and Engineering: C, 103, 2019: pp.109770. https://doi. org/10.1016/j.msec.2019.109770 